\title{
Beyond the Colonial Shadow? Delinking, Border Thinking, and Theoretical Futures of Cultural History
}

\author{
It's as if the colonial event belonged to another age and another place, and as if it had abso- \\ lutely nothing to teach us about how to understand our own modernity, about citizenship, \\ about democracy, even about the development of our humanities. \\ (Mbembe 2006, 4)
}

\section{A Past Future: The Birth of New Cultural History and the Boom of Anthropological Theories}

In the year 1989, Lynn Hunt proclaimed nothing less than the beginning of a new cultural history (Hunt 1989, 10) and pleaded for consequential anthropological theoretical receptions. Already eight years prior, Natalie Zemon Davis wrote, "anthropology can widen the possibilities, can help us take off our blinders, and give us a new place from which to view the past and discover the strange and surprising in the familiar landscape of historical texts" (Davis 1981, 275). In Germany in 1984, Hans Medick published his legendary - and subsequently updated article Missionaries in the Rowboat? stating that anthropological knowledge and theories could help enlighten the "complex mutual interdependence between circumstances of life and the concrete practice" of historical actors - their "experiences and modes of behavior" (Medick 1995, 43).

All three authors, and many other cultural historians, argued against socio-historical approaches that they considered deficient, particularly due to their theoretical framework. During the late 1980s and early 1990s, new cultural history, as well as historical anthropology (a specific German version of cultural historical approaches), were coined by the constant pleas for an injection of anthropological theories and methods into historical theoretical and methodological approaches. Anthropology might help, the argument went, to see the past as a "strange foreign territory" and the everyday life of historical actors akin to those of “"primitive' or 'archaic' societies” (Davis 1981, 272). With this approach,

Note: I thank my research assistant A. Tancrède Pagès for his important remarks, corrections, and the editing.

Ә Open Access. (C) 2020 Hubertus Büschel, published by De Gruyter. (๕)BY-NC-ND This work is licensed under a Creative Commons Attribution-NonCommercial-NoDerivatives 4.0 International License.

https://doi.org/10.1515/9783110669398-008 
new innovative research could be pushed forward in order to produce analyses less determined by socio-historical master narratives and present prejudices but rather by local experiences and negotations as well as multiperspectivity or counternarratives. Quite similar was the second major influence in the formation of new cultural history, French post-structuralism, notably Michel Foucault's work on discourse (see Burke 2008, 56).

In this article, I will critically discuss this "paradigmatic shift" (Kuhn $1970,6)$ - this anthropological and poststructural turn - that was so fundamental in the formation of new cultural history. When Achille Mbembe said, in a 2006 interview, that colonialism seems to be far away and seems to belong "to another age and another place" (Mbembe 2006, 4), he hit the neuralgic point of central theories within new cultural history. While anthropologists had already considered the need for methodological and theoretical revisions in their discipline, in part due to the colonial heritage of their epistemic landscape (Comaroff 2010; Kohl 2010), cultural historians have paradoxically argued for a quite ahistorical reception of the very same anthropological theories derived from colonial research practices that have been criticized by the aforementioned anthropologists.

To illustrate this line of argument, I will analyze in the following article three central anthropological theories that have been thoroughly integrated into cultural history and cultural studies. By concentrating on these three examples, I wish to emphasize the colonial roots of anthropological theories and the ways in which they allow for, and cloak, analytical shortcuts and heuristic, theoretical, and methodological assumptions. The examples to be examined are as follow: ritual theory by Victor Turner, Pierre Bourdieu's concept of 'habitus,' and last, but not least, Michel Foucault's discourse analysis. I will also reflect upon the individual experiences these scholars had with colonialism - this might give us an idea about the "thought style" (Fleck 1979, 38-50) that pushed forward their thoughts and was subsequently reflected in their theories. At the end of the article, I will discuss scholarly efforts to overcome the colonial limits of cultural historical theories. Altogether, I would like to offer some space to discuss the futures of cultural history, allowing for the reconsideration and reformation of cultural historical theories. In the last decades, scholars have formulated tools for going beyond colonial shadows and eurocentric perspectives including 'delinking' and 'border thinking.' These tools might be helpful in efforts revolving around the decolonization and revision of cultural historical theories. I will shortly introduce and discuss these tools and ventilate their possible benefits for the theoretical future of cultural histories. 


\section{The Danger of Rituals: Victor Turner and the Homogenous Societies}

Since the 1980s and 1990s, cultural historians have worked extensively with anthropological ritual theories (Bell 1997), particularly those of Victor Turner and his approach to liminality (Turner 1964, 1969; Deflem 1991). Turner, in developing Arnold van Gennep's (1960 [1909]) threefold structure of rituals of passage further, argues that rituals are usually based on a "liminal phase" with several "liminal spaces" followed one after another. These spaces are categorized in observed transitions performed over the course of a ritual. Turner was primarily interested in the transitions in which individuals were - as he wrote - "betwixt and between" (1964), exceeding and crossing boundaries of the liminalities of rituals that would create a sense of community among all involved (Turner 1967, 1969).

In reference to Turner, the sociologist and anthropologist David Kertzer proclaimed that rituals have a key role in the formation and cohesion of social groups. They make it possible to create social consensus even if there are substantive contradictions within or conflicts among the social groups. Through their constant repetition, rituals ensure the maintenance of social bonds. On the other hand, they are also to be constantly adapted to changing political conditions in order to maintain their socially stabilizing effect (Kertzer 1988, 189-196).

These assumptions made anthropological ritual theory, with all its symbolic interpretations, tremendously attractive for cultural historians; rituals seemed to represent key phases and elements of societal developments. Meanwhile, liminality appeared to give answers to questions of historical change and to the question of how societies are organized and restructured. Historical change can be seen as being condensed in the 'in between' phases of rituals.

Already in the 1970s, Natalie Zemon Davis worked with ritual theories for her analyses of violence and its religious roots in seventeenth-century France (1973). Subsequently, Roger Chartier $(1984,1989,1990)$ investigated structures of experiences with the help of Turner's ritual theories and drew conclusions from the manifestations of rituals on the intentions of the organizers of these rituals and the perceptions, feelings, and thoughts of their participants. In Germany, Barbara Stollberg-Rilinger promoted ritual theories for the cultural historical analyses of early modern forms of governance (2013). Johannes Paulmann revisited the classical field of monarchical meetings in the long nineteenth century. In line with Turner and Kertzer's observations on rituals, Paulmann came to the conclusion that symbolic presentations of power would have had a direct impact on political relations (2000, 402-416). Both authors contributed to new and innovative interpretations within the field of political history and showed how rituals can 
establish, negotiate, and structure power relations. Altogether, the works mentioned above demonstrated how ritual theory can offer novel research findings. Most notably, it could cast analytical light on overlooked or ignored public rituals, ceremonies, and performances that were important elements of societal and political expression and negotiation. Although receptions of anthropological theories of ritual have undoubtedly led to new, innovative interpretations of more classical political-historical phenomena, the theoretical premises of ritual theory are problematic in that it becomes increasingly difficult to disentangle them from colonial ways of producing and accruing knowledge.

Similar to most of his contemporaries, Turner was deeply involved in the colonial establishment; he worked in Northern Rhodesia (modern day Zambia) as a research officer for the Rhodes-Livingstone Institute (RLI). The RLI, founded in 1938 to conduct demographic studies on the local population, was the first anthropological research facility in Sub-Saharan Africa. It was mainly financed by the Colonial Office in London (Schumaker 1996, 238-240). Therefore, it was clearly embedded within the colonial system of governance, contrary to constant official claims that the RLI would stand for liberal and anti-racist research promoting African independence (Brown 1973). Turner, like all researchers of the institute, was tasked with providing colonial authorities with useful information about the customs, needs, and thoughts of the natives to facilitate colonial rule by avoiding conflicts and frictions with and within colonized populations. It is within this context that we have to understand Turner's studies on the Ndembu people (Turner 1967). In his approach on 'social drama,' he took the experiences of colonialism and colonial civilizing missions into account to develop his theories about rituals as a form of symbolic conflict management and crisis resolution in the Ndembu villagers' society living between 'traditional' and 'modern' life - he was also interested in the experiences of cultural suppression and losses caused by the colonial encounters. Turner's research, in combination with the needs to serve the colonial authorities with information for their future policies, had to deal with the assumptions of a quite homogenous Ndembu society following the notion of the colonial concept of a static and, in its practices, 'mechanistic' (Comaroff 2010, 531) 'tribe' (Ekeh 1990). Turner's conception of the liminality of rituals and his focus on the 'tribe' can be explained with his training as a colonial expert; individuals were not of interest here. Instead, the focus lied on collective moods and events as these were the categories through which colonial experts could plan and calculate their policies. The figure of the 'tribe' as a constructed and imagined basic social unit was central. It conditioned the ways in which colonial administrators negotiated, planned, and eventually deployed their modes of governance entailing systematic cultural oppression through so-called 'civilizing missions.' In addition, Turner's theoretical roots and role models were 
profoundly colonial. Above all he was influenced by the founding father of British anthropology, Edward B. Tylor, who, among others, had developed the so-called "animistic theory" that emanated from the "soulfulness of magical-sacral presentations in primitive societies” (Tylor 1871, 424). By 1871, Tylor wrote that it was through magical rites and symbols in a "primitive" society that a collective belief could be evoked alongside a "sacralization and ensoulment" of all individuals in a society (Tylor 1871, 424).

As Suzanne Desan, among others, has pointed out, this notion seeped into the reception of anthropological theories of ritual in the new cultural history and formed itself primarily for "the methodological assumption that an analysis of the patterns of crowd activism will reveal its meaning and offers clues about community structures” (Desan 1989, 56). This approach was deeply criticized by scholars, such as the medieval historian Philippe Buc, who coined the slogan "dangers of rituals" and pointed to the heuristic problems of inferring the forms of rituals on their intentions, perceptions, and receptions. Buc claimed that individual resistance, reservations, or simply social performances without social consequences have to be taken into consideration (Buc 2000, 183-186, 2001, 8-11). While Buc and others objected to the methodological and heuristic shortcuts of anthropological theories of ritual, one can also assume that it would be possible to draw conclusions from the appearance of rituals that their intentions and effects were to be determined by colonial thoughts in two respects: First, the theories are reminiscent of typical colonial conceptualizations of native societies as homogenous, static, and passive; second, we can see the deeply colonial and even racist conception of ceremonies that everything has a cohesive meaning of the highest value within so-called 'primitive societies' or community. A similar, but slightly different, conception of community can also be found in Pierre Bourdieu's cultural historical theories, principally in his concept of "habitus" (Bourdieu 1977).

\section{In the Imperial Gaze: Pierre Bourdieu's Colonial Concept of "Habitus"}

In the aforementioned 1989 key publication New Cultural History, Aletta Biersack praises the usefulness of Bourdieu's theory of practice for cultural historians when they are interested in investigating the practical side of everyday life in the past (Biersack 1989, 90). Roger Chartier was influenced by Bourdieu's theory of practice as well as by ritual theory (Burke 2008, 59). Simon Schama, in his famous book The Embarrassment of Riches (1987), analyzed several "Dutch 
obsessions" like the ongoing preference of cleanliness through Bourdieu's concepts of "habitus" and "distinction" (see Gorski 2013).

Like Turner, Bourdieu had his own colonial experiences. In the year 1955 he arrived in Algeria during the war of independence. Once there, he absolved his military service and was first employed as a typist at the Air Force and then as a clerk at the news and documentation service of the General Government in Algiers. Bourdieu was fascinated by the country. He decided to stay and took over the position as a lecturer at the University of Algiers. In the following months, he became interested in anthropology and started to conduct fieldwork on the colonized Algerian society.

Bourdieu undertook two intensive, and sometimes dangerous, field studies: the first on the living conditions in cities during the war; the second on villages in rural Kabyle in northern Algeria hedged in between the Atlas mountain range on the one side and the Mediterranean See on the other. People from Berber societies and peasants who were imprisoned in French resettlement camps were the predominant demographic living in this region (Free 1996; Herzfeld 1987, 7-8; Lane 2000, 13-16). Around three million people - nearly half of the Muslim rural population - were relocated by force not only for 'security reasons' but also to push forward development programs of 'modernization.' These camps were structured like village communities in order to push forward a variety of colonial development programs including "modern agriculture," "rational economies," and "everyday life hygiene” (Wilder 2003, 2005; Büschel 2014, 169-171).

Bourdieu was aware of the colonial violence the establishment and operation of these camps represented as well as the ways in which the French civilization mission had caused deep political, social, and cultural ruptures within the Kabyle societies. He called the colonial development and education programmes "social vivisection" and "social surgery" (Bourdieu 1962, 131-133). There is no doubt that Bourdieu shared critical thoughts about colonialism as a racist system of suppression and domination, enforced through violence, manifest in both physical and psychological force, that destroys and restructures social relations (Go 2013, 49-74).

In spite of possessing deep sympathy for the colonized Algerians, illustrated by his profound critique of colonialism (Wacquant 2004), Bourdieu never adhered to the Third Worldism promoted by Jean-Paul Sartre, Frantz Fanon, and others (Kalter 2016; Le Sueur 2001; Ahluwalia 2010). In fact, he opposed Third World activists who seemed to him far too involved in promoting violence. The depth of Bourdieu's involvement in the mental horizons and style of thoughts of French colonizers becomes clear when analyzing his theoretical conceptions (Seibel 2004; Yacine 2003, 2004, 2008; Go 2013, 51). During his time in Algeria, and alongside his fieldwork in the Kabyle villages, Bourdieu developed his most central 
concepts for new cultural history in "symbolic capital” and "habitus" (Bourdieu 1977, 1990; Hammoudi 2009; Goodman 2009; Silverstein 2009). He did this while describing the Kabyle society in terms such as "collective consciousness" - very much in line with the epistemic culture of colonial expertise (Bourdieu 1977).

Critics argue that Bourdieu cultivated in his early writings a "romantic redemption of ethnic culture" (Burawoy 2011, 8) as well as a "structural nostalgia” about the local cultures, seen as passive and defensive instead of active and creative (Silverstein 2009). Edward Said and others have accused Bourdieu of developing Eurocentric theories and of being an example of a European scholar who constantly portrays non-Western societies as "different, static and homogenous" (Said 1989; Go 2013, 50). Furthermore, the concept of 'habitus' carries assumptions quite similar to ritual theory. Foremost, it makes it possible for one to draw conclusions about the social conditions of groups from a phenomenological analysis of incorporated collective intentions and thoughts (Callhoun 2006, 1403). Bourdieu has thus been criticized for sharing, or even reproducing, the imperial gaze of colonial knowledge systems (Go 2013, 50).

Indeed, the late and post-colonial humanitarian attitude of the colonial expert or development worker went hand in hand with deep colonialism implications as can be seen in Bourdieu's theoretical assumptions. It should be taken seriously that concepts like 'habitus' are entangled with ethnocentric colonial collectivism and systematic silencing of the colonized 'Others.'

\section{Eurocentric Discourse and Knowledge: Michel Foucault and Colonialism}

Similar to ritual theory and Bourdieu's concept of 'habitus,' Michel Foucault's theoretical assumptions became fundamental for new cultural history. Three aspects have been particularly influential. First, in his notions about discourse, Foucault seemed to serve the linguistic turn, which also deeply affected cultural history, whilst simultaneously asserting that discourse always means practice and that words are highly political and embedded in dispositives and governmentality. Therefore he also served the needs for theoretical framing of the study of practices in the past. Second, Foucault opposed ideas of teleological developments or progress in history. Instead, he emphasized discontinuities, ruptures, and shifts, which conforms to new cultural history's opposition against socio-historical master narratives. Finally, Foucault's attempt for 'epistemes' and 'regimes' of truth has been met with interest by many cultural historians investigating the cultural and historical development of ideologies and knowledge (Burke 2008, 56-57). 
The important influence of Foucault on both cultural history and postcolonial studies can be traced in Said's study Orientalism (1978) that examines the West's patronizing and imperialistic representations of 'The East' - the people and their cultures who inhabit areas in Asia, North Africa, and the Middle East. Foucault's concept of 'discourse' was central for Said (1978, 48-49). Many scholars have criticized Said for employing a determining univocal and unidirectional notion of discourse. This was seen as a result of Foucault's reception within historical research, especially “The Order of Discourse” (1981), in which Foucault stressed the restrictive and homogenizing qualities of discourses as tools of power and violence (Foucault 1981; Young 1995, 60; Nichols 2010). The most prominent critique of Foucault's theories and their reception in cultural history was raised by Gayatri Spivak who wrote that Foucault's analysis would carry the "danger" of re-inscribing the West as a subject of analysis (Spivak 1985, 18, 1988, 291; Kaplan 1995, 90).

Similar to Turner and Bourdieu, Foucault had his own (post-)colonial experience. He arrived in Tunis in 1966 to take over a teaching position at the University of Tunis. Tunisia became a constitutional monarchy and gained independence from France on March 20, 1956 but was still determined by colonial elements in its governance, like an autocratic police state lacking any democratic element. Foucault lived in the coastal village Sidi Bou Said, known for its romantic atmosphere, occupied since 1900 by numerous European artists such as August Macke and Paul Klee. Shortly after his arrival in Tunis, there were violent clashes between students and authorities (Lazreg 2017, 176). Foucault's biographers claimed that the immense violence of the police entering the university campus, injuring students, and arresting them had a great impact on Foucault's thoughts who finally supported the protests in multiple ways including hiding a printing machine in his garden to clandestinely produce critical leaflets on behalf of students (Lazreg 2017, 177).

Taking these experiences into account, it is remarkable that Foucault's theoretical assumptions and his thoughts about discourse, dispositive, and governmentality almost completely lacked reasoning about race and colonialism (Young 1995, 5). Timothy Mitchell noted that the narrative of history in Foucault's writing is coined by a deep eurocentrism and is the story of Europe (2000, 3-7). Time and space are imagined homogenously; encounters, influences, cultural transfers, or entanglements from the non-West are irrelevant (Fernández and Esteves 2017, 141). The 'normalization' of suppression, discipline, power, punishment, and violence that Foucault describes in his writing is the narrative of "everywhere" (Foucault 1977, 304) and is thus a universal 'truth' that disregards, and ahistoricizes, its embedment within the Western classical Westphalian model of statehood and governance. 
Considering this, it seems quite paradoxical that Foucault was the most cited theorist in studies about colonialism in the last decades (Stoler 1995, 1). One could say colonial studies with Foucault might carry the danger of Western asymmetries and silencing locals, thus necessitating innovative critical re-assessments and reflections of how his theories are implemented in the field of study.

\section{Theoretical Futures? Decentering, Delinking, and Border Thinking}

Taking into account the colonial limits of the aforementioned theories in new cultural history, it becomes clear that the theoretical futures in the study of culture need revisions and reformulations. In addition to the colonial shadows of these theories, one could argue alongside Dipesh Chakrabarty that new cultural history and the pleas for anthropology and post-structuralism carry typical elements of Western historiography's historicism of universalizing attempts to come closer to something that one may call the "truth about the past" (Chakrabarty 2000, 6-11; Young 1990, 142).

Since the early 2000s, scholars from all over the world have claimed a fundamental epistemic turn in the study of culture and therefore also in new cultural history (Grosfoguel 2007); they have called the result of this set of theoretical operations 'decoloniality.' 'Decoloniality' does not mean post-colonialism or adding post-colonial perspectives to research agendas and perspectives. Indeed, it does not seem to be fruitful to just add post-colonial theories to the canon of cultural historical concepts. 'Decoloniality' is a more fundamental approach with a whole set of operations to move "beyond the post-colonial" (Mignolo 2007, 452).

One of the operations gaining theoretical 'decoloniality' is 'decentering,' brought up by Natalie Zemon Davis as a response to Chakrabarty: 'Decentering' refers to new heuristic perspectives with particular emphasis on cultural crossings and counter-histories (Davis 2011, 190-191). Therefore 'decentering' includes the stance and the subject matter of the historian. The 'decentering' historian does not tell the story of the past from the "vantage point of a single part of the world or of powerful elites, but rather widens his or her scope, socially and geographically, and introduces plural voices into the account” (Davis 2011, 190).

A recent form of 'decentering' can be found in the initiative of Ulinka Rublack that has led to a collection of articles by historians. Rublack asked several experts to 'decenter' their own professional views and standpoints and to write about areas, approaches, and periods beyond their expertise in order to gain new and fresh analyses beyond the established self-confidence (2011). Davis' claims and 
Rublack's initiative were important steps of 'decentering' on the way to 'decoloniality.' But both approaches still remained within the context of Western historiographical epistemology when it comes to methods, theories, and narratives. What we need is a more fundamental epistemological 'delinking' and 'decentering' from Western and sometimes even colonial dominated forms of thought.

An early example of this radical fundamental cultural historical 'decentering' is First-Time: The Historical Vision of an African American People, authored by the anthropologist Richard Price (1983). Oral testimonies, songs, stories, and artefacts of the Saramacca Marrons from the Suriname rainforest are composed together; the result is a masterpiece of historical bricolage, full of nonhierarchically presented records and thoughts about a formerly marginalized and silent society and their past experiences in violence, suppression, and slavery. 'Decentering' here means the absence of a master narrative and any voices of external Western observers, which makes it possible to perform a history of the peoples their own.

Walter Mignolo goes far beyond the non-hierarchical multiplication of voices in his attempt to de-silence the silenced. He speaks vehemently for a radical epistemic 'delinking' in the theories of cultural studies - the 'delinking' from heuristic, theoretical analytical, and methodological approaches from Western thought and culture (Mignolo 2007, 2009). This might entail the abandonment of Western modes of reasoning and epistemological practices and their replacement by 'indigenous' or 'local' thoughts. 'Delinking' implies the destruction of colonial networks of knowledge and power in order to give those who have historically been silenced a voice. This can happen with heuristic operations but also with theoretical 'delinking.' This introduces crucial theoretical questions: can we 'delink' ritual theory from its colonial framing sketched above and what is left then? Can we go beyond the colonial attitude of studying liminality with the holistic presumption of a crowd of individuals' feeling and thinking all the same in a ritual process (Desan 1989, 56)? Does bypassing the "dangers of rituals" with the heuristic operation of inferring the forms of rituals on their intentions, perceptions, and receptions mean that ritual theory have to come to an end (Buc 2000, 183-186, 2001, 8-11)? I do not think that this has to automatically and consequently be the case. 'Delinking' ritual theories from its colonial methodological and theoretical presumptions can mean 'decentering' the heuristic perspective and its analysis away from the form of rituals to its local conditions and commentators (Davis 2011, 190). Furthermore, in cultural history rituals are oftentimes seen as a form of societal cohesion and governance in a constant field of balance and imbalance between obedience and resistance (Desan 1989, 57). Already quite some time ago, Jean and John Comaroff coined the phrase of a "dialectically neomodern" analysis, which means a constant attention on transformations, 
processes, hegemonic practices, and cultural boundaries (Comaroff and Comaroff 1992, xi-24). Indeed, the colonial shadow of ritual theory also carries a potential; tracing it and taking it into account can help us to understand and criticize our own hegemonic practices and open our analyses for further critical reflections about the non-homogenic, non-linear, and non-conform. Therefore, theoretical 'decentering' and 'delinking' can have at least three dimensions. The first revolves around switching theoretical perspectives beyond hegemonic Western epistemic systems; the 'Other,' the supposed peripheral becomes central or at least a field of reasoning, discussion, and exchange. Second, there is a methodological-heuristical dimension that attempts to excavate and listen to marginalized and silenced sources of historical epistemology. Finally, there is the chance for constant critical revisions of hegemonic epistemic master narratives on the path for the multiplication of narrated analyses (Adichie 2009).

After 'delinking' might follow 'border thinking' (Anzaldúa 1987; Mignolo and Tlostanova 2006, 206), which focuses on all those theoretical and conceptual approaches that are so far excluded from the master narratives of cultural studies - these include different concepts of time, space, narration, plausibility, and epistemology. All these theories beyond the Western - or even beyond the colonial matrix of epistemic power - should help establish an "epistemology of the exteriority; that is, of the outside created from the inside" (Mignolo and Tlostanova 2006, 206). 'Border thinking' can also favor the creation of new analytical narratives beyond "epistemic ranking" and Western knowledge based hierarchies (Mignolo and Tlostanova 2006, 214). In practice, 'border thinking' could mean not just multiple narratives - like we can see it in 'decentering' - but also multiple theories with a new sensitivity of alternative knowledge traditions beyond Western hegemony as well as alternative theoretical inspirations - or at least the non-hierarchical multiplication of theories. Therefore 'border thinking' can produce a "redefinition/subsumption of citizenship, democracy, human rights, humanity, economic relations beyond the narrow definitions imposed by European modernity," how Ramón Grosfoguel points it out (Grosfoguel 2006, 178). [However] "border thinking is not an anti-modern fundamentalism. It is a decolonial transmodern response of the subaltern to Eurocentric modernity" (Grosfoguel 2006, 178-179). What can this mean in the practice of cultural historical analysis?

Can 'border thinking' help us to liberate concepts like Bourdieu's 'habitus' from its imperial gaze as it was described above? Bourdieu has been criticized for implementing a colonial view in concepts like 'habitus' (Go 2013, 50) by drawing conclusions of a human being's behavior and applying generalized projections onto inherent collective thoughts, feelings, or customs. Should we therefore give up 'habitus' and forget about an insightful tool for generations of sociologists, 
scholars of cultural studies, and historians whose goal is to trace the connection between human environment and behavior? Mignolo writes that "border thinking' is "de-subalternizing knowledge" itself and can help to pluralize epistemic frameworks as well as make the "rigidity of epistemic and territorial frontiers" in assumptions visible (Mignolo 2000, 12-67). It might be useful to reread concepts like 'habitus' beyond the rigidity of Western presumptions and to understand that the phenomenology of the 'habitus' as well as the customs, feelings, and thoughts are localized and in constant fluidity between individuals and their live worlds, kinship, and societal relations. What could be given up by 'border thinking' and concepts like 'habitus' is the danger of holistic/universal conclusions; what could be preserved is a postcolonial turned tool for historical and societal analyses and the ambivalences, fluidity, locality, and last but not least wonderful diversity of human behavior in the past. Similarly, 'border thinking' offers great potential as a critical tool in reconfigurations of the Foucauldian concepts of dispositive and governmentality and its eurocentric determination (Young 1995, 5; Mitchell 2000, 3,7). 'De-subalternizing' mechanisms of power, influence, and governance might help to trace 'other' non-Western - but also "modern" (Grosfoguel 2006, 178-179) - governmental tools and show the pluralities of concepts in constant negotiations of societal domination, participation, and resistance far beyond the state and its Westphalian model.

In sum, I hope to have sketched that 'decentering,' 'delinking,' and 'border thinking' might be possible tools for a new theoretical future of cultural history beyond Western and colonial presumptions as "eternal and untouchable truths" (Rose 1997, 308). These approaches might help us to de-colonize important anthropological, social, and philosophical theories that were central for generations of cultural historians. Furthermore, they might help us to inspire rereadings and rethinking practical cultural historical research and prepare the theoretical design of cultural history more for the future of global exchange and local epistemic cultures.

\section{References}

Adichie, Chimamanda Ngozi. The Danger of a Single Story. https://www.ted.com/talks/ chimamanda_adichie_the_danger_of_a_single_story?language=en. Ted Talk, 2009 [accessed: 22 March 2019].

Ahluwalia, Pal. Out of Africa: Post-structuralism's Colonial Roots. New York: Routledge, 2010. Anzaldúa, Gloria. Borderlands/La Frontera: The New Mestiza. San Francisco: Aunt Lute Books, 1987.

Bell, Catherine. Ritual: Perspectives and Dimensions. Oxford: Oxford University Press, 1997. 
Biersack, Aletta. “Local Knowledge, Local History: Geertz and Beyond.” The New Cultural History. Ed. Lynn Hunt. Berkeley/Los Angeles/London: University of California Press, 1989. 72-97.

Bourdieu, Pierre. The Algerians. Boston: Beacon Press, 1962.

Bourdieu, Pierre. Outline of a Theory of Practice. Cambridge: Cambridge University Press, 1977. Bourdieu, Pierre. The Logic of Practice. Palo Alto: Stanford University Press, 1990.

Brown, Richard. "Anthropology and Colonial Rule: Godfrey Wilson and the Rhodes Livingstone Institute." Anthropology and the Colonial Encounter. Ed. Talal Asad. New York: Humanities Press, 1973.

Buc, Philippe. "Ritual and Interpretations: The Early Medieval Case." Early Medieval Europe 9.2 (2000): 183-210.

Buc, Philippe. The Dangers of Ritual: Between Early Medieval Texts and Social Scientific Theory. Princeton: Princeton University Press, 2001.

Burawoy, Michael. Sociology as a Combat Sport: Bourdieu Meets Bourdieu. http://burawoy. berkeley.edu/Bourdieu/2.Combat.pdf. 2011 [accessed: 22 March 2019].

Burke, Peter. What is Cultural History? 2nd ed. Cambridge: Polity Press, 2008.

Büschel, Hubertus. Hilfe zur Selbsthilfe. Deutsche Entwicklungsarbeit in Afrika 1960-1975. Frankfurt a.M.: Campus, 2014.

Callhoun, Craig. "Pierre Bourdieu and the Social Transformation: Lessons from Algeria." Development and Change 37.6 (2006): 1403-1415.

Chartier, Roger. "Culture as Appropriation: Popular Cultural Use in Early Modern France." Understanding Popular Culture: Europe from the Middle Ages to the 19th Century. Ed. Steven Kaplan. Berlin/New York/Amsterdam: Mouton Publishers, 1984. 229-254.

Chartier, Roger. “Le monde comme representation.” Annales 44.6 (1989): 1505-1520.

Chartier, Roger. Les origines culturelles de la révolution française. Paris: Le Seuil, 1990.

Chakrabarty, Dipesh. Provincializing Europe: Postcolonial Thought and Historical Difference. Princeton: Princeton University Press, 2000.

Comaroff, John. "The End of Anthropology, Again: On the Future of an In/Discipline." American Anthropologist 112.4 (2010): 524-538.

Comaroff, Jean, and John Comaroff. Ethnography and the Historical Imagination. Boulder, CO: Westview Press, 1992.

Davis, Natalie Z. “The Rites of Violence: Religious Riot in Sixteenth-Century France." Past and Present 59.1 (1973): 51-91.

Davis, Natalie Z. "Anthropology and History in the 1980s." Journal of Interdisciplinary History 12.2 (1981): 267-275.

Davis, Natalie Z. “Decentering History: Local Stories and Cultural Crossings in a Global World.” History and Theory 50.2 (2011): 188-202.

Deflem, Mathieu. "Ritual, Anti-Structure, and Religion: A Discussion of Victor Turner's Processual Symbolic Analysis." Journal for the Scientific Study of Religion 30.1 (1991): 1-25.

Desan, Suzanne. "Crowds, Community, and Ritual in the Work of E.P. Thompson and Natalie Davis.” The New Cultural History. Ed. Lynn Hunt. Berkeley/Los Angeles/London: University of California Press, 1989. 47-71.

Ekeh, Peter P. "Social Anthropology and Two Contrasting Uses of Tribalism in Africa." Comparative Studies in Society and History 32.2 (1990): 660-700.

Fernández, Marta, and Paula Esteves. "Silencing Colonialism: Foucault and the International." Foucault and the Modern International: Silences and Legacies for the Study of World 
Politics. Eds. Philippe Bonditti, Didier Bigo, and Frédéric Gros. New York: Palgrave Macmillan, 2017. 137-153.

Fleck, Ludwik. Genesis and Development of a Scientific Fact. Chicago: University of Chicago Press, 1979.

Foucault, Michel. Discipline and Punish: The Birth of the Prison. New York: Vintage Books, 1977. Foucault, Michel. "The Order of Discourse." Untying the Text: A Post-Structuralist Reader.

Ed. Robert J. C. Young. London: Routledge, 1981. 51-76.

Free, Anthony. "The Anthropology of Pierre Bourdieu: A Reconsideration." Critique of Anthropology 16.4 (1996): 395-416.

Gennep, Arnold van. The Rites of Passage. Chicago: University of Chicago Press, 1960 [1909]. Go, Julian. "Decolonizing Bourdieu: Colonial and Postcolonial Theory in Pierre Bourdieu's Early Work.” In: Sociological Theory 31.1 (2013): 49-74.

Goodman, Jane E. "The Proverbial Bourdieu: Habitus and the Politics of Representation in the Ethnography of Kabylia." Bourdieu in Algeria: Colonial Politics, Ethnographic Practices, Theoretical Developments. Eds. Jane E. Goodman and Paul Silverstein. Lincoln, NE: University of Nebraska Press, 2009. 94-132.

Gorski, Philip S., ed. Bourdieu and Historical Analysis. Durham, NC/London: Duke University Press, 2013.

Grosfoguel, Ramón. "World-Systems Analysis in the Context of Transmodernity, Border Thinking, and Global Coloniality." Review 29.2 (2006): 167-187.

Grosfoguel, Ramón. “The Epistemic Decolonial Turn: Beyond Political-Economy Paradigms.” Cultural Studies 21.2/3 (2007): 211-223.

Hammoudi, Abdellah. "Phenomenology and Ethnography: On Kabyle Habitus in the Work of Bourdieu." Bourdieu in Algeria: Colonial Politics, Ethnographic Practices, Theoretical Developments. Eds. Jane E. Goodman and Paul Silverstein. Lincoln, NE: University of Nebraska Press, 2009. 199-254.

Herzfeld, Michael. Anthropology Through the Looking Glass. Cambridge: Cambridge University Press, 1987.

Hunt, Lynn. "Introduction: History, Culture and Text.” The New Cultural History. Ed. Lynn Hunt. Berkeley/Los Angeles/London: University of California Press, 1989. 1-22.

Kalter, Christoph. The Discovery of the Third World. Cambridge: Cambridge University Press, 2016.

Kaplan, Martha. "Panopticon in Poona: An Essay on Foucault and Colonialism." Cultural Anthropology 10.1 (1995): 85-98.

Kertzer, David I. Ritual, Politics, and Power. New Haven, CT/London: Yale University Press, 1988.

Kohl, Karl-Heinz. “The End of Anthropology - An Endless Debate.” Paideuma: Mitteilungen zur Kulturkunde 56 (2010): 87-98.

Kuhn, Thomas S. The Structure of Scientific Revolutions. Chicago: University of Chicago Press, 1970.

Lane, Jeremy F. Pierre Bourdieu: A Critical Introduction. London: Pluto Press, 2000.

Lazreg, Marnia. Foucault's Orient: The Conundrum of Cultural Difference from Tunisia to Japan. New York: Berghahn Books, 2017.

Le Sueur, James D. Uncivil War: Intellectuals and Identity Politics during the Decolonization of Algeria. Philadelphia: University of Pennsylvania Press, 2001.

Mbembe, Achille. "What is Postcolonial Thinking? An Interview with Achille Mbembe." Edition Esprit 12 (2006): 117-133. 
Medick, Hans. “'Missionare im Ruderboot'? Ethnologische Erkenntnisweisen als Herausforderung an die Sozialgeschichte." Geschichte und Gesellschaft 10.3 (1984): 295-319.

Medick, Hans. “'Missionaries in the Row Boat'? Ethnological Ways of Knowing as a Challenge to Social History." The History of Everyday Life: Reconstructing Historical Experiences and Ways of Life. Ed. Alf Lüdtke. Princeton: Princeton University Press, 1995. 41-71.

Mignolo, Walter. Local Histories/Global Designs: Coloniality, Subaltern Knowledges, and Border Thinking. Princeton: Princeton University Press, 2000.

Mignolo, Walter. "Delinking." Cultural Studies 21.2 (2007): 449-514.

Mignolo, Walter. “Epistemic Disobedience, Independent Thought and Decolonial Freedom.” Theory, Culture \& Society 26.7/8 (2009): 159-181.

Mignolo, Walter, and Madina V. Tlostanova. "Theorizing from the Borders: Shifting to Geo- and Body-Politics of Knowledge.” European Journal of Social Theory 9.2 (2006): 205-221.

Mitchell, Timothy. "The Stage of Modernity." Questions of Modernity. Ed. Timothy Mitchell. Minneapolis: University of Minnesota Press, 2000.1-34.

Nichols, Robert. "Postcolonial Studies and the Discourse of Foucault: Survey of a Field of Problematization.” Foucault Studies 9 (2010): 111-144.

Paulmann, Johannes. Pomp und Politik. Monarchenbegegnungen in Europa zwischen Ancien Régime und Erstem Weltkrieg. Paderborn: Schöningh, 2000.

Price, Richard. First-Time: The Historical Vision of an African American People. Chicago: University of Chicago Press, 1983.

Rose, Gilian. "Situating Knowledges: Positionality, Reflexivities and Other Tactics." Progress in Human Geography 21.3 (1997): 305-320.

Rublack, Ulinka. A Concise Companion to History. Oxford: Oxford University Press, 2011.

Said, Edward. Orientalism: Western Representations of the Orient. London: Routledge, 1978.

Said, Edward. "Representing the Colonized: Anthropology's Interlocutors." Critical Inquiry 15.2 (1989): 205-225.

Schama, Simon. The Embarrassment of Riches: An Interpretation of Dutch Culture in the Golden Age. New York: Alfred A. Knopf, 1987.

Schumaker, Lynette. "A Tent with a View: Colonial Officers, Anthropologists, and the Making of the Field in Northern Rhodesia, 1937-1960.” Osiris 11.2 (1996): 237-258.

Seibel, Claude. "Les liens entre Pierre Bourdieu et les statisticiens à partir de son expérience Algérienne." La liberté par la connaissance: Pierre Bourdieu (1930-2002). Eds. Jacques Bouveresse and Daniel Roche. Paris: Odile Jacob, 2004. 105-119.

Silverstein, Paul. "Of Rooting and Uprooting: Kabyle Habitus, Domesticity and Structural Nostalgia.” Bourdieu in Algeria: Colonial Politics, Ethnographic Practices, Theoretical Developments. Eds. Jane E. Goodman and Paul Silverstein. Lincoln, NE: University of Nebraska Press, 2009. 164-198.

Spivak, Gayatri Chakravorty. "Subaltern Studies: Deconstructing Historiography." Selected Subaltern Studies. Eds. Ranajit Guha and Gayatri Chakravorty Spivak. Oxford: Oxford University Press, 1985. 3-32.

Spivak, Gayatri Chakravorty. "Can the Subaltern Speak? Speculations on Widow Sacrifice." Marxism and the Interpretation of Culture. Eds. Cary Nelson and Lawrence Grossberg. London: Palgrave Macmillan, 1988. 271-313.

Stoler, Ann Laura. Race and the Education of Desire: Foucault's History of Sexuality and the Colonial Order of Things. Durham, NC/London: Duke University Press, 1995.

Stollberg-Rilinger, Barbara. Rituale. Frankfurt a.M.: Campus, 2013. 
Turner, Victor W. "Betwixt and Between: The Liminal Period in Rites de Passage." Symposium on New Approaches to the Study of Religion: Proceedings of the 1964 Annual Spring Meeting of the American Ethnological Association. Ed. June Helm. Seattle, WA: University of Wisconsin Press, 1964. 4-20.

Turner, Victor W. The Forest of Symbols: Aspects of Ndembu Ritual. Ithaca: Cornell University Press, 1967.

Turner, Victor W. The Ritual Process: Structure and Anti-Structure. Chicago: University of Chicago Press, 1969.

Tylor, Edward B. Primitive Culture: Researches into the Development of Mythology, Philosophy, Religion, Art and Costume. Vol. 1. London: John Murray, 1871.

Wacquant, Loïc. "Following Bourdieu into the Field." Ethnography 5 (2004): 387-414.

Wilder, Gary. "Colonial Ethnology and Political Rationality in French West Africa." History and Anthropology 14.3 (2003): 219-252.

Wilder, Gary. The French Imperial National-State: Negritude and Colonial Humanism Between the Two World Wars. Chicago: University of Chicago Press, 2005.

Yacine, Tassadit. “L’Algérie, matrice d'une oeuvre.” Travailler avec Bourdieu. Ed. Pierre Encrevé. Paris: Flammarion, 2003. 333-345.

Yacine, Tassadit. "Pierre Bourdieu in Algeria at War: Notes on the Birth of an Engaged Ethnosociology." Ethnography 5 (2004): 487-509.

Yacine, Tassadit. "Aux origine d'une ethnosociologie singulière." Pierre Bourdieu, Esquisses algériennes. Ed. Tassadit Yacine. Paris: Éditions du Seuil, 2008. 23-53.

Young, Robert. White Mythologies: Writing History and the West. London: Routledge, 1990.

Young, Robert. "Foucault on Race and Colonialism." New Formations 25 (1995): 57-65. 